\title{
HUKUK KLINIIKLERİ: BEKLENTİLER, UYGULAMALAR VE KKTC HUKUK FAKÜLTELERİ AÇISINDAN OLANAKLAR
}

\section{$\ddot{O} Z$}

\section{Duygu HATIPPOĞLU AYDIN*}

Hukuk kliniği, hukuk eğitiminin geleneksel biçimine alternatif bir yaklaşım sunan, birbiriyle bă̆lantıl iki önemli amaca yönelmiş bir ĕ̆itim ve ögretme metodudur. Hukuk eğitim modelinin katı ve şekilci yaklaşımının sonucunda, hukuk fakültesinden mezun olan ögrenciler, hukuk uygulaması hakkında bilgi sahibi olmadan mezun olup, meslek hayatına atılmaktadır. Hukuk kliniklerinin pedagojik hedefi meslek ögrretmek ve her türlü deneyime dayal, uygulamalı ve katılımcr eğitimdir. Öğrencilerin çeşitli beceriler ve değerler kazanmaları amaçlanırken, bu hedeflerin sağlanması, hukuk hizmetini alacak kişilere kaliteli bir hizmetin verilmesi sonucunu doğuracaktır. Dolayısıyla iyi ve etkili bir hukuk eğitimi, sunulacak adalet hizmetinin kalitesini de belirleyecektir. Bu amaçlara yönelmiş hukuk klinikleri farklı biçimlerde sürdürülmektedir. Klinik çalışmalarının farklı yapılanmasında o bölgenin sosyoekonomik ve kültürel koşullarl, dolayısıla hukuksal bağlam önem arzetmektedir. Türkiye'de hukuk klinikleri, hukuk eğitimindeki aksaklıkların çözümü bağlamında, son yılların önemli konu başlıklarından biridir. Türkiye'de hukuk eğitiminin geleneksel biçimine karşı, hukuk kliniklerinin "deneyimsel ögrenme” yaklaşımı farklı hukuk fakültelerinde hayata geçirilmektedir. Kuzey Kıbrıs Türk Cumhuriyeti'nin hibrid hukuki yapısı ve farkl kültürlerden beslenen sosyal karakteri, adada ögrenim gören hukuk fakültesi öğrencileri açısından, farklı bir hukuk kliniği deneyimi să̆layabilir ve kliniklerden beklenen faydayı artıran unsurlar olarak değerlendirilebilir.

Anahtar Kelimeler: Hukuk eğitimi, hukuk klinikleri, deneyim, hukuk uygulaması, adalete erişim.

\section{LEGAL CLINICS: EXPECTATIONS, PRACTICES AND, POTENTIALS FOR TRNC LAW FACULTIES}

A legal clinic is an alternative to traditional legal education. Because of the formalist approach of legal education model, students graduated from law faculty have a minimum idea about the practice and go into professional life. The pedagogical scope of legal clinics comprises technical education and applied and participatory training based on all kinds of experience. Students gaining various skills and values will improve the quality of the legal service. Therefore, a good and useful law education will determine the quality of the justice service to be offered. Legal clinics directed

* Dr. Öğretim Üyesi, Uluslararası Final Üniversitesi Hukuk Fakültesi. e-posta: duygu. hatipoglu@gmail.com, duygu.aydin@final.edu.tr.

DOI : 10.34246/ahbvuhfd.609106

Yayın Kuruluna Ulaştığı Tarih : 05/03/2019

Yayınlanmasının Uygun Görüldüğ̈̈ Tarih: 22/05/2019

Ankara Hacı Bayram Veli Üniversitesi Hukuk Fakültesi Dergisi C. XXIII, Y. 2019, Sa. 3285 
to these purposes are carried out in different ways. In the different structuring of clinical studies, the socioeconomic and cultural conditions of the region and thus, the legal context are essential. In Turkey, legal clinics are one of the important topics of legal education in the context of troubleshooting of the educational system. Against traditional forms of legal education in Turkey, the "experiential learning" approach of legal clinics are being implemented in different law schools. The hybrid legal structure and the rich social character of Turkish Republic of Northern Cyprus can have many advantages for the law students on the island and can increase the expected benefit from legal clinics.

Key Words: Legal education, legal clinics, experience, law in action, access to justice

\section{GÍRIŞ}

Hukuk klinikleri, düşünce olarak 1900'lerin başında ortaya çıkmış ve zamanla gelişmiş, günümüzde dünya çapında yaygın, pek çok farklı uygulaması bulunan ve Türkiye'de hukuk fakültelerinde verilen eğitimin yeni ve önemli başlıklarından biri olarak hukuk eğitiminde dikkate değer bir yaklaşımdır.

$\mathrm{Bu}$ çalışmada hukuk kliniklerinin doğuşu ve gelişimi üzerine kısa bir girişten sonra, Türkiye'deki hukuk eğitimi, hukuk klinikleri uygulaması ve hukuk kliniklerinin KKTC'de uygulanabilirliği üzerine bir değerlendirme yapılacaktır.

Bu bağlamda çalışmanın çıkış noktası, hukuk eğitimindeki, sadece ders anlatma biçimine indirgenemeyecek problemlerin varlığıdır. Peki hukuk klinikleri, hukuk eğitimindeki mevcut krize bir alternatif olabilir mi? Eğitime farklı yaklaşımıyla Türkiye'deki mevcut klinik uygulamaları, beklentileri ne şekilde karşılamaktadır? Bu değerlendirmeler 1şığında, Kuzey Kıbrıs'ta bir hukuk kliniği çalışması gerekli midir ve neler yapılabilir?

$\mathrm{Bu}$ sorular cevaplandırılırken çalışma birkaç bölüme ayrılmıştır. İlk bölümde, hukuk kliniklerinin ortaya çıkış koşulları ve gelişimi, farklı ülke uygulamaları ile özetlenecektir. Hukuk klinikleri, biçim olarak ilhamını tıp eğitiminden alan ve hukuk eğitiminin geleneksel yöntemlerine karşı alternatif bir yaklaşım sunan, birbiriyle ilişkili iki önemli amaca yönelmiş bir eğitim ve öğretme metodudur. Pek çok önerme bulunan bu cümleyi unsurlarına ayırırsak, farklı başlıklar hakkında tespitler yapmak gereklidir. Buna göre, öncelikle, hukuk eğitiminde geleneksel yöntemlerin ne olduğu, hukuk kliniklerinin 
hangi ihtiyaca yönelik olarak önerildiği ve tıp eğitimi ile nasıl bir ilişki içinde olduğu sorularına cevap verilecektir. Farklı ülke uygulamalarından ve örnek klinik modellerinden bahsedilecektir. İkinci bölümde Türkiye'de mevcut hukuk eğitiminin tarihsel süreç içindeki gelişimine bakılacak ve hukuk klinikleri ihtiyacı ve uygulamaları bu bağlamda değerlendirilecektir. Türkiye uygulamasından örnekler verilerek, Kuzey Kıbrıs'ta hukuk kliniği çalışmalarının avantaj ve dezavantajları üzerinde durulacaktır. Bu çalışma ile hukuk klinikleri konusunda genel bir değerlendirme yapılması ve Kuzey Kıbrıs Türk Cumhuriyeti'ndeki üniversiteler için öneriler getirilmesi, bir hukuk kliniği çalışması için temel oluşturulması amaçlanmaktadır.

\section{HUKUK KLIINIKLERİ: NEDEN VE NASIL?}

Hukukun ayırtedici özelliklerinden biri, hukukun yalnız bilgi değil, duygu olarak da ele alınmasıdır. Hukukun konusu "yalnız insan düşüncesine değil, yüreğine de yerleşmiştir." ${ }^{1}$ Hukuk eğitimi de hukuk alanının özgül ihtiyaçlarına göre düzenlenmiştir ve onun özelliklerini taşır. Bunun anlamı, hukuk sosyal olguya dayanmakla birlikte, hukuk kural, bu sosyal olgunun ve korunmas1 amaçlanan değerin olabildiğince soyutlanarak bir kural haline getirilmesidir. Hukuk eğitimi de bu soyut sonuca, yani norma odaklanmıştır. Cahit Can, normu, içeriğinden soyutlanmış (kendisel) ve normun içerik kazandırılmış hali (materyal norm) olarak ikiye ayırır ve bir kuralın hukuku yansıtabilmesi ya da hukuk kuralı sayılabilmesi için, başta adalet olmak üzere, toplumsal yaşamın birtakım değerlerine uygun olması gerektiğini belirtir. ${ }^{2}$ Hukukun dışsallaştırılmasının bir aracı olarak hukuk normu ${ }^{3}$ anlatılırken, o normun doğumuna sebep olan tarihsel ve toplumsal koşullar, olgunun bir norm haline gelmesi için duyulan ihtiyaç ve o normun konulmasıyla korunması amaçlanan değer ve normun değeri ayrıntılı şekilde açıklanmaz. Bunun farklı sebepleri olduğu söylenebilir. Örneğin konunun genişliği nedeniyle, her normun ayrıntısına girilmesi beklenemez. Bu pratik değildir. Bunun dışında, hukuk, soyut kurallar sistemi olarak kendi fikri dünyasını yaratır, kendi başına bir varlıkmış, kendi başına bir sistemmiş gibi ele alınır. Onu yaratan koşullardan ve ortamdan soyutlanarak aktarılır. Hukuk ilim olarak değerlendirildiğinde, pozitif bilimler gibi soyut, kesin, genel geçer kuralları hukuk öğrencisine belletilir. Burada eğitim, içeriğinden soyutlanmış hukuk normuna/kuralına

\footnotetext{
1 V. KRİCHMANN, s. 194.

2 CAN, s. 25.

3 CAN, s. 26-28.
}

Ankara Hacı Bayram Veli Üniversitesi Hukuk Fakültesi Dergisi C. XXIII, Y. 2019, Sa. 3287 
ve mevzu hukuka odaklanmaktadır. Haliyle, hukuk kuralının uygulanması aşamasında, yani "gerçek hayatta" işler farklılaşmaktadır. İnsana dair, toplumsal değerleri içeren ve karmaşık bir değerler ve kurallar bütününden süzülmüş normun uygulaması da oldukça karmaşık ve çok yönlü olmaktadır. $\mathrm{Bu}$ noktada sözü, Mariano D'Amelio'ya birakmak gerekiyor. Hukuk kliniklerine dair makalesinin çevirisi 1936 yılında yayınlanmıştır. Yazdıkları, 1900'lerin başında hukuk algısına ve eğitimine dair çok şey söylemektedir':

“(...) hukuk bir iyilik ve hakkaniyet sanatıdır: Ars boni etaequi. Fakat hakikatte bu tarife uygun olan hukuk değil, mahkeme içtihatlarıdır (giurisprudenza). İçtihatların teessüsüne hizmet etmeyen ve insanlar arasında adaletin en iyi şekilde tatbikini kendisine hedef almamış olan Hukuk beyhudedir. Aristokratik bir fikir yorgunluğundan başka bir şey değildir. Bunun içindir ki Hukukçuların realitelerle, ve işlerin her günkü hareketlerinden, gösterdikleri krizlerden bu işler üzerinde çıkan ihtilaflardan, mahkemelerdeki faaliyetlerden, avukat ve noter bürolarında cereyan eden hadiselerden müteşekkil olan "Ameli hukuk hayatı" ile temasa gelmeleri zarureti duyulmaktadır. Bu yorucu, maddi ve mütevazl "ameli hayat" içinde büyük ve meşhur Üniversitelerde ögrenilen nazariyeler mefhumlar, uzak, gayri maddi ve hayali bir alemden gelen seslere benzemektedir. İste mektepten yeni çıkmış bir gencin bulunduğu vaziyet budur."

D'Amelio'nun vurguladığı "hukukun bir sanat (esasında zanaat) olması fikri”, hukuk eğitiminin de gündemindedir. Otto Kahn Freund'a göre hukuk eğitiminin bir amacı, mezunlarının hukukçu olmasına yetecek teknik bilgi edinmesi ama diğer yandan hukuk formasyonu almalarıdır. Ancak bu sayede hukukçu olabilirler. ${ }^{5}$ Peki bu noktada eğiticiler ne yapacaktır? Kahn-Freund, hukuk eğitimindeki "otoriteleri" eleştirerek, buradaki öğrenmenin "kitabi" olduğunu, öğrencilerin kitabın içeriğini ezberleyip, kitaptan çıkarımlar yapmaya çabaladığını belirtir. Kitabın kendisini sorgulamak, ne öğrencinin ne de hocanın işidir. Kahn-Freund, bunun aslında hukukun karakteri olduğunu söyler. ${ }^{6}$ Tuğrul Ansay, Kahn-Freund'un bahsettiği teknik bilginin "ilim olarak hukuka", hukuk formasyonunun da "san'at olarak hukuka" denk düștügünü vurgular. ${ }^{7}$

\footnotetext{
4 D'AMELIO, s. 71.

5 KAHN-FREUND, s. 123.

6 KAHN-FREUND, s. 124.

7 ANSAY, s. 278.
}

288 Ankara Hacı Bayram Veli Üniversitesi Hukuk Fakültesi Dergisi C. XXIII, Y. 2019, Sa. 3 
Görüldüğü gibi hukuk klinikleri modeline duyulan ihtiyacın temelinde, hukukun dogmatik karakteriyle bağlantılı dogmatik bir eğitim modelinin benimsenmiş olması vardır. Her ne kadar hukuk klinikleri fikri oldukça eskiye götürülebilirse de ${ }^{8}$, modelin, başlangıçta istisnai olduğundan bahsedilebilir. Hukuk klinikleri modelinin yaygın şekilde benimsenmesi için başka koşulların varlığ 1 da gerekmiştir. Dünya değiştikçe hukuk da değişmiş, farklı bir eğitim yaklaşımının cevap verebileceği farklı ihtiyaçlar ortaya çıkmış ve özellikle 60'lı yıllardan itibaren hukuk klinikleri yaygınlaşmaya başlamış ve artık 1990'lara gelindiğinde görmezden gelinemeyecek ya da istisna olarak nitelendirilemeyecek bir akım halini almıştır.

Bu noktada eğitim modelinin katı ve şekilci yaklaşımı, bunun sonucu olarak da hukuk öğrencilerinin pratikte olup biten hakkında fikir sahibi olmaksızın mezun olmaları her dönem açısından neredeyse sabit bir veridir. Kliniklerin yaygınlaşması, boşluk problemi denilen, normatif düzenlemeler ile uygulamaları arasındaki farklılığın görmezden gelinemeyecek bir hal alarak tartışıldığı bir süreçle eş zamanlı olmuştur. Bu süreç aynı zamanda, mevzuatın karşılayamadığı yeni ihtiyaçların ortaya çıkışıyla da bağlantılıdır. Burada kritik noktalardan biri "adalete erişim"in anlamındaki değişimdir. Refah devletinin yükselişiyle "sistemin herkes için eşit şekilde erişilebilir olması" ve "sistemin bireysel ve toplumsal olarak adil sonuçlara yol açması" temel amaçlarına odaklanan ve devletin genel himayesi altında olan adalet sisteminin ${ }^{9}$ uyuşmazlıkları adil şekilde çözebileceği iddiasının somutlaşmış biçimi adalete erişimdir. Ancak zaman içinde adalete erişim de, toplulukların adalet ihtiyaçlarının niteliği de, dolayısıyla bu hizmeti verecekler de değişmiştir.

RoderickA. Macdonald, adalete erişime dair tartışmalardaki değişiklikleri beş dalga halinde tarifler. İlk dalgada adalete erişim, yani 1960'larda mahkemelere ve avukatlara erişim olarak anlaşılır. İkinci dalgada, adli yardımın yetersizliklerinin de görülmesiyle mahkemelerin performansı sorgulanmaya başlanmış, bu da üçüncü dalgadaki "adalete erişimde eşitlik" prensibinin güçlenmesine neden olmuştur. 90'larla birlikte önleyici hukuk hedefi ön plana çıkmış, işte bu noktada klinikler, semt adalet merkezleri, anlaşmazlıkları önleyici gayrı resmi kuruluşlar ve uzlaştırma ön plana çıkmıştır. Artık adalete erişim, yasaların uygulandığı kadar, oluşturulduğu ve yürütüldüğü kurumlara

\footnotetext{
8 Hukuk eğitiminde farklı yöntemlerin ABD'de 1870'lerde ortaya çıkışı ve geldiği nokta hakkında bir değerlendirme için bkz. MINOW, s. 2279-97.

9 CAPPELLETTİ ve GARTH, s. 182.
} 
kamunun katılımını içerecek şekilde geniş anlaşılmaya başlanmıştır. Nihayet beşinci dalga adalete erişim, hukuk sistemi içindeki tüm birimlere ve otoritelere tam kapasite ulaşılabilmesi, dışlanmışlar için eşit firsatlar olarak algılanmaktadır ${ }^{10}$. Hukuk kliniklerinin iki önemli amaç ve hedefinden biri olan dezavantajlı grupların adalete erişimlerinin güçlendirilmesi, adalete erişim algısının böyle bir süreç içinde değişmesi sonucu bir ihtiyaç olarak ortaya konmuştur. Gerçekten, hukuk klinikleri ilk olarak adli yardım hizmeti olarak başlamıştır. Bunda, hem profesyonel hukukçuların hem de hukuk akademisyenlerinin, hukuk önündeki sistemik eşitsizliği vurgulamak amacıyla adalete erişim hareketine katılmaları etkili olmuştur. Profesyoneller ve akademisyenlerin bu ortak kaygısı, dünya çapında adli yardım ve klinik hukuk eğitimi arasında düzenli ve somut ilişkiler kurulmasına yol açmıştır. ${ }^{11}$ Böylelikle, hukuk klinikleri bir yandan hukuk eğitiminin dogmatik biçimine karşı bir eleştiri olurken, diğer yandan da dezavantajlı grupların adalete erişim süreçlerini kolaylaştıracak, hatta bu grupların hukukla temas etmesine vesile olacak bir model olmuştur. Tekrar vurgulamak gerekirse, hukuk kliniklerinin ikili bir işlevi vardır. Bir tarafı, hukuk eğitiminin eksikliklerine bir cevap, diğeri de adalet mekanizmalarına çeşitli sebeplerden erişemeyen bazı kırılgan ve dezavantajları grupların hukuki bilgiye erişimini sağlamaktır.

Hukuk eğitimiyle adalete erişim arasında ilişki, hukuk eğitiminin hedefleriyle birlikte düşünülünce daha açık hale gelir. Hukuk klinikleri, öncelikli pedagojik hedefini "avukatlık mesleğini öğretmek" olarak belirlemiş, her tür deneyime dayalı, uygulamalı ve katılımcı eğitimi ifade eder. Bu hedef profesyonelliğin gelişimi ile orantılı olarak yetenekler ve değerler alanı içermektedir. Bunlar, hukuki sorunları çözebilme kabiliyeti, eksiksiz temsil, etik ikilemleri tanıma ve çözüme ulaştırma, adaletin savunucusu olma, adil olma ve ahlaktır. ${ }^{12}$ Genel olarak hukuki hizmetler diyebileceğimiz hukuk alanında verilecek çeşitli hizmetler belirli bir grup insana özgülenmiştir ve bu kişilerin hukuk eğitimi almaları zorunludur. Avukat, hakim, savcı, bilirkişi, arabuluculuk gibi farklı hukuki hizmetleri sağlayacak hukuk öğrencilerine, birtakım beceri ve değerlerin hukuk eğitimi sürecinde kazandırılması gerekir. $\mathrm{Bu}$ beceri ve değerlerin artırılması için hukuk eğitiminin eksikliklerinin giderilmesi gerekir.

\footnotetext{
10 MACDONALD, s. 23-25.

11 BLOCH ve NOONE, s. 156.

12 WILSON, s. 79.
} 
Hukuk klinikleri hukuk eğitiminin uygulamadan kopuk olma, bilgi verme ancak beceri geliştirememe şikayetlerine bir cevap olarak ortaya çıkmıştır. Çünkü "hukukçular ne yaparsa yapsınlar adaletin sunulmasında vazgeçilmez rol oynarlar. Sağliklı yarg1 sisteminin en önemli göstergelerinden biri hukukçuların kalitesi ve dürüstlügüuür."13 Dolayısıyla iyi ve etkili bir hukuk eğitimi, sunulacak adalet hizmetinin kalitesinin de belirleyicilerindendir.

Hukuk kliniklerine gösterilen ilgideki artış, adli yardım pratiklerindeki zayıflamayla da bağlantılıdır. Adli yardım, adalete erişim sürecinin önemli unsurlarından biridir. Esas olarak doğru hukuki bilgiye ve hukuksal temsile erişimi kapsar. Ancak dünya genelinde adli yardım hizmetlerinin ciddi bütçe kesintileri yoluyla azaltılması söz konusudur. $\mathrm{Bu}$ aynı zamanda refah paradigmasının zayıflaması sürecinde ve ortadan kalktı̆̆ yeni düzende, devletin doğrudan sorumlu olduğu adli yardım hizmetlerinin daraltılması, refah devletinin taşıııcı sütunlarından birinin zayıflaması olarak değerlendirilmiştir. ${ }^{14}$ Sosyal refah devletinin dönüşümü, özelleştirme, deregülasyon, refah haklarının zayıflaması ve adalete erişimde yeni yönelimler olarak kendini göstermeye başlamıştı. ${ }^{15}$ İşte böyle bir durumda hukuk klinikleri ile devletin yükümlü olduğu bir alanın, eğitimciler ve özel kurumlar tarafindan doldurulmasının söz konusu olduğu söylenebilir. Tek başına hukuk kliniklerinin bu boşluğu doldurması mümkün olmamakla birlikte, ilgilileri açısından adalete erişim yollarının değişmesi ve çeşitlenmesi söz konusudur. Türkiye açısından Adalet Bakanlığı Stratejik Planında yer alan hedeflerden biri "adalete erişim ile mağdurlara ve dezavantajlı gruplara yönelik uygulamaları geliştirmek"tir. Bu hedef kapsamında hukuki yardım sigortası sisteminin geliştirilmesi, zaman yönetimi uygulamasının yerleştirilmesi, çocuk adaleti sisteminin güçlendirilmesi, dezavantajlı gruplara duyarlı bir sistem oluşturulması, koruyucu hukuk uygulamalarının geliştirilmesi gibi alt hedeflerin yanında, "hukuk kliniği yöntemlerinin geliştirilmesi" hedefi belirlenmiş ${ }^{16}$ ve hukuk kliniklerinin yaygınlaşmasına ilişkin stratejiler saptanmıştır. Adalet Bakanlığı'nın 2015 tarihli Yarg1 Reformu Stratejisinde, hukuk klinikleri, bir yandan öğrencilerin uygulama ile bağını güçlendirirken, diğer yandan dezavantajlı grupların adalete erişimini kolaylaştıran bir

\footnotetext{
13 CHODOSH, s. 329.

14 HOWARD.

15 EDGEWORTH, s. 175.

16 Adalet Bakanlığı, Stratejik Plan, s. 92.
} 
yöntem olarak tanımlanmıştır. ${ }^{17} \mathrm{Bu}$ tarif, hukuk kliniklerinin ikili amacını özetlemektedir.

Hukuk kliniğinin yöntemi, "deneyimsel öğrenme" olarak tarif edilebilir. $\mathrm{Bu}$ öğrenme yönteminde, öğrencilerin öğrendikleri şeyler üzerine kafa yorması amaçlanır. Öğrenciler, hem toplum hakkında öğrendiklerini ve hukukun toplumdaki rolünü hem de kendileri hakkında öğrendiklerini ve bunların arasından kendilerini bir gün iyi bir avukat yapacak şeylerin neler olduğunu düşünmeye davet edilmektedirler: ${ }^{18}$

Öğrencilere avukatlık becerileri adını verdiğimiz pek çok beceriyi öğretmeye çalışlyoruz. Müvekkille görüşme: bir müvekkille nasıl görüşülür, nasıl danışmanlık yapılır, müvekkile nasıl tavsiye verilir; mesleki sorumluluk: bir avukatın ilişkilerini yönlendiren etik kurallar nelerdir; savunma: mahkemede nasıl inandırıcı bir savunma yaratılır; müzakere: nasıl müzakere edilir; eleştirel düşünme: tamam, kanun böyle söylüyor, sanki kanun bize karşı gibi görünüyor, haydi araştıralım, deneyip başka bir şey yapabilir miyiz bir bakalım; problem çözme: problemleri nasıl çözeriz, avukatın hayatı devamlı problem çözmektir; taslak hazırlamak: belgeleri nasıl hazırlarız; belgeleri tasarlamanın önemi: yanlıs yere nokta veya virgül koyamazsınız, size milyonlara mal olur; iletişim becerileri: nasıl konuşuyorsunuz, nasıl yazıyorsunuz, nasıl iletişim kuruyorsunuz, telefonunuzu nasıl kullanıyorsunuz ve ayakta nasıl düşünüyorsunuz.

Deneyimsel öğrenme, hukuki hizmetlerin kapsamı düşünüldüğünde, büyük bir ihtiyaç olarak ortaya çıkmaktadır. Hukuk uygulaması, hukukun yöneldiği adalet değeri ile de bağlantılı şekilde, öncelikle insanların sorunlarına, çoğu zaman mutsuzluk kaynaklarına dairdir. Çoğu hukuk öğrencisi, eğitim sürecini tamamladıktan sonra birdenbire, kendilerinden "adalet" yani çözüm bekleyen kişilerin mutsuzlukları ve sorunlarıyla başbaşa kalıyor. Travma yaşayan birinin problemini dinleyip onu hukuken sınıflandırmak ve çözüm için bir yol önermek görevi sırasında, o travmaya saplanıp kalabiliyor. Krizi yönetmeye dair hiçbir fikirleri olmuyor, insanlarla nasıl konuşulur, yaptıkları iş, verdikleri hizmet hakkında nasıl bilgi verirler, söyledikleri karşı tarafta nasıl yankılanır, onu dahi bilemiyor olabiliyorlar. Mezun öğrencilerin, bütün bu yüklerle ilk kez karşılaştıkları ve bunları tek başlarına yüklendikleri bir kurgudan ziyade, henüz öğrenciyken gerçek insanların gerçek problemleriyle

17 Adalet Bakanlığı, Yarg1 Reformu, s. 92.

18 McQUOID, s. 10-31.

292 Ankara Hacı Bayram Veli Üniversitesi Hukuk Fakültesi Dergisi C. XXIII, Y. 2019, Sa. 3 
bir grup içinde, bir öğretim üyesinin denetiminde ve desteğiyle karşılaşmaları sonucunda, meslek hayatlarında karşılacakları travmalarla başa çıkmaları daha kolay olacaktır. Öğrenciler mezun olduklarında bu sorunlarla tek başlarına karşılaşmaktansa, bunu henüz öğrenciyken görürler ve kriz çözme, insanlarla konuşma ve benzeri konularda deneyim kazanırlar. Klinik uygulaması öğrencilere böylesi bir deneyim sağlar. Ayrıca hukuk eğitiminde kliniklerin işlevini öğrencilerin eğitim süreci bakımından da değerlendirmek gerekir. Örneğin öğrenciler ortalama iki aylık periyodlarla sinavlara girip değerlendiriliyorlar. Çalışırken yalnızlar. Ama klinik çalışmaları grup çalışmasıdır. Öğrenciler birlikte düşünme ve eyleme pratiği kazanırlar. Avukat, hakim veya savcı olarak, problemlerin çözümünde birlikte çalışma kültürünün ne kadar önemli olduğu açığa çıkacaktır çünkü adaletin tesis edilmesi ekip işidir. Ayrıca, mesleğe başladıklarında tek başlarına yüklenmek zorunda kalacakları çeşitli problemleri, önceden görüp, bir öğretim üyesiyle ve diğer arkadaşlarıyla birlikte deneyimlerler. ${ }^{19}$

Hukuk kliniği eğitiminde esas olan deneyimsel öğrenme, tıp eğitimine benzer. Bu bağlamda, hukuk fakültelerinin/ okullarının tıp fakültelerinden öğrenecekleri çok şey olduğu tespiti, klinik fikri kadar eskidir. ${ }^{20}$ Klinik düşüncesinin temelinde bu ihtiyaç ve benzerlik yatar. Nasıl ki tıp okullarında öğrenciler eğitim hastanelerinde gerçek hastalarla iletişim kuruyor, gerçek hastalıkları görüyorlarsa, hukuk öğrencileri için de bu geçerli olabilir. Eğitim hastanelerinde hastalar yardım alır, öğrenciler bilgilerini artırır, becerilerini geliştirir ve teoriyi pratikte uygulayarak yeterlilik sahibi profesyoneller olarak çalışırken, yetkin doktorlar da geçerli kalite standartlarının korunmasından sorumludur. ${ }^{21}$ Böylesi bir benzeşme olmasının sebebi, hem hukukun hem tıbbın konusunun insan olması ve her iki alanın da insanın sorunlarına odaklanmasıdır. Jerome Frank, klinikler sayesinde öğrencilerin mahkemelerin düşüncesi ve hukukçuların pratiği arasındaki ilişkiyi doğrudan gözlemlemeyi öğrenebileceklerini belirtir. Öğrenciler, jürilerin nasıl karar verdiğini, kararlarına etki eden unsurları; olguların belirsiz kararkterlerini/özelliklerini; yasal hakların nasıl tanıkların hafiza bozukluklarına, önyargılarına ve yalan beyanlarına bağlı olduğunu; hakimlerin yorgunluğunun, açıkgözlüğünün, politik ilişkilerinin, rüşvet almasının, tembelliğinin, vicdanlı olmalarının, sabır veya sabırsızlıklarının, önyargılı ya da açık fikirli olmalarının etkilerini;

\footnotetext{
19 AZAPAĞASI et al. (Richard Grimes konuşması), s. 30.

20 FRANK, s. 917.

${ }^{21}$ GRIMES, s. 72.
} 
anlaşma biçimlerini ve uyuşmazlıkların çözüm yöntemlerini; bunların yanında "adalet sisteminin işleyişinin insani yönünü görebilirler". ${ }^{22}$

Hukuk kliniklerinin her birinin çıkış noktasının farklı olduğunu ve yerelin özgün dinamikleri ile şekillendiğini belirtmek gerekiyor. Bunun sebebi her eğitim sisteminin ve adalet sisteminin farklı ihtiyaçları olmasıdır. Bu nedenle farklı yerlerdeki klinik çalışmaları kendi özgünlükleri ile gelişirler. Ancak dünyada üzerinde ortaklaşılan bir kaç klinik tipi olduğu söylenebilir ${ }^{23}$ :

1. Kurum içi klinikler: Burada genelde fakülte içinde bir danışma biriminde, öğrencilerin hukuki görüş bildirmeleri söz konusudur.

2. Dışa açık yöntem: Bu yöntemde okul klinikten sorumludur ama kliniğin fiziksel mekanı okul dışındadır. Bir toplum merkezi ya da başka bir kurumun odası kullanılmaktadır.

3. Yerleştirme: Öğrencilerin bir kuruma yerleştirilip burada staj yapmaları sağlanmaktadır.

4. Street Law (halka açık hukuk okur yazarlı̆̆l, gündelik hayatta hukuk): Öğrenciler halkın hakları ve sorumlulukları hakkında bilgilendirme çalışmaları yaparlar. Bunun için genelde belirli bir grup belirlenir; çocuklar, kadınlar, cezaevindeki mahkumlar gibi. Öğrenciler bu grubun hakları ve yükümlülükleri ile ilgili araştırma yapar, sonra da bunu ilgili topluluklara anlatırlar. Bunun oldukça etkili bir öğrenme yöntemi olduğu belirtilmektedir.

$\mathrm{Bu}$ hukuk kliniklerinin hepsinde ortak payda hukuki hizmetlerin münferit müvekkillere veya toplumsal gruplara veriliyor olması ve hukuk öğrencilerinin müvekkillerle mülakat yapma, ilgili hukuki görüşleri araştırma gibi temel sorumlulukları üstlenmesidir. Sonuçlar ve teklif edilen öneriler hukuki olarak geçerlilikleri ve uygunlukları kontrol edildikten sonra, klinik müvekkile istenen yardımı sunmaktadır.

Bundan başka iki klinik tipi de yaygın olarak kullanılmaktadır. Bunlardan biri yasal reform projeleridir. Burada öğrenciler kanun önerileri hazırlar veya değişiklik önerilerini değerlendirir. Simülasyon ise, hukuk ilkelerinin uygulanması konusunda öğrencilerin pratik kazanmasını sağlamak amacıyla kurgusal senaryolar çerçevesinde rol yapma esasına dayanan bir yöntemdir. ${ }^{24}$ $\mathrm{Bu}$ modellerin Türkiye uygulamalarına aşağıda değinilecektir.

\footnotetext{
22 FRANK, s. 918.

23 GRIMES, s. 75-76.

24 AZAPAĞASI et al., Richard Grimes konuşması, s. 95-96.
} 
Klinik çalışmalarını yerelin özgün dinamiklerinin şekillendireceği kabulünün yanında, bir yandan da küresel bir klinik hareketinden bahsedilebilir. $\mathrm{Bu}$, kliniklerin, hukuk öğrencilerinin ve dolayısıyla geleceğin hukukçularının gündelik-pratik hukuk faaliyetine ilişkin becerilerinin geliştirilmesi ve ögrencilerin etik ve profesyonel sorumluluklarının artırılması hedefinden öte bir noktayı tarifliyor. Hukuk öğrencilerinin dikkatini yalnızca etik yükümlülükler ve sorumluluklara değil, hukukun ve hukukçuların toplumdaki gücüne ve değiştirici etkisine çekebilen bir klinik hukuk eğitiminin, yeni nesil hukukçuların dünyada bir fark yaratmasını sağlayabileceği, küresel bir klinik hareketinin de bu amaç doğrultusunda çalışabileceği vurgulanıyor. ${ }^{25}$

\section{TÜRKIYE'DE HUKUK EĞITTIMI}

Türkiye'de kurumsal olarak hukuk eğitimi, İstanbul Üniversitesi'nde başlamıştır. 1933 yılında, üniversite reformu kapsamında Darülfünun kapatılmış, İstanbul Üniversitesi adını almış ve bir üniversite olarak yapılandırılmaya çalışılmıştır. Bu değişikliğin sebebi, üniversitenin her şeyden önce spekülatif düşüncenin odak noktası ve kaynağı olması, bunu hayata geçireceklerin de bilim insanları olması gerektiği düşüncesidir. Ernst Hirsch, bunun gerekçesini “bu sebeple bir meslek yüksekokulu değil, Türkiye'de Batı Avrupa üniversitelerinin ayarında, gerçeği araştıran ve derinleştiren, bilgiyi toplayan, düzenleyen, çoğaltan ve yayan bir bilim yuvası niteliğinde bir bilim kurumu kurmak amac1" olarak belirtir. ${ }^{26}$ Yeni adiyla İstanbul Üniversitesi Hukuk Fakültesi'nde Darülfunundan kalma İslam Hukuku öğretme geleneğinin pek de kırılamaması, öte yandan memlekette görev yapacak daha çok hakimin yetiştirilmesi için Ankara Hukuk Mektebi kurulur. ${ }^{27}$ Tuğrul Ansay, Ankara Hukuk Mektebi'nin kuruluşunu ve gelişmelerini anlattığ

25 BLOCH ve MENON, s. 270.

26 HIRSCH, s. 211.

27 1926'ya kadar, Medrese'de öğretilen hukuk olan İslam hukuku, insanlar arası ilişkileri ve gündelik hayatın işlerini kurallara bağlama ve düzenleme konularında, özünde İslamın ögretilerince belirlenmişti. Hirsch, 1926'da resepsiyon sonrası, yürürlükten kaldırılan hukukun de facto olarak varlığını sürdürdüğünü, çünkü yürürlüğe konulan yeni kanunların de facto uygulanmadığını vurgular. Ne zaman ki halk ve hukukçular bu kanunları uygulayacaklar, o zaman kanunların ifade ettiği ideal düzen gerçek olabilecekti. Yeni kanunların kabul ettirilmesi açısından hukuk öğretiminin ve hukuk öğretisinin taşıdığı merkezi önem de yeterince kavranmamıştı. Hirsch, hukukta radikal değişiklikler olurken, İstanbul Hukuk Fakültesi'nin, sadece yeni kanunları müfredat programına almakla yetindiğini, oysa çok daha fazlasına ihtiyaç olduğunu vurgulayarak, Ankara Hukuk Mektebi'nin kuruluşunu bu sebebe de bağlar. HİRSCH, s. 226-28; Benzer bir tartışma için bkz. AKÇAOĞLU, s. 373-74. 
1965 tarihli makalesinde, teorik ve pratik eğitim modelinden bahsetmektedir. 1941 yılında Ankara Hukuk Mektebi'nde eğitim yılı 4 yıla çıkarılmış ve ilk kez "ameli" dersler kabul edilmiştir. Ameli derslerin amacı ise "talebelerin ders programına dahil mevzuları bizzat incelemeleri ve bu suretle muhakeme kabiliyetlerini geliştirmelerini temin" olarak açıklanmaktadır. Programa dahil olan mevzularla alakalı kanun metinlerinin şerhi, mahkeme içtihatları ile müelliflerin fikir veya tenkitlerinin izahı, muhtelif dersler arasındaki alaka ve irtibatın mütalaası ve bu mevzularda talebeye münakaşalı konferanslar verdirilmesi gibi mesailer de kapsama alınıyor. ${ }^{28}$

O dönem müfredatı zenginleştiren ameli derslerin bugünkü karşıllı̆ 1 "pratik kur çalışması"dır. Farklı hukuk derslerinde öğrenciler varsayımsal bir olay üzerinden, teorik olarak öğrendikleri konu veya kanun maddelerini olaya uygularlar. Böylece ilgili konu pekiştirilir. Bunun dışında hukuk fakültelerinde ders yöntemi "takrir"dir; yani anlatma, ders verme. ${ }^{29}$ Pratik kur çalışmaları yöntemi, Alman hukuk eğitiminde mevcut olan ve Ankara Hukuk Mektebi tarafindan benimsenen bir model olmuştur. ${ }^{30}$ Esasen hukuk eğitiminde teorinin ve pratiğin birbirinden ayrılması 1870'lerde Alman sisteminde hukuk eğitimi ve tatbikatın ayrılmasıyla gerçekleşmiştir. Ve uygulama/tatbikat hukuk fakültelerinden sonraya bırakılmıştır. Türkiye'de genel olarak Alman sisteminden etkilendiği söylenebilir. Akademik aşamada pratik oldukça zayıftır. $^{31}$

Tuğrul Ansay'ın 1965 tarihli makalesinde bahsettiği hususların günümüzde hala geçerli olduğunu belirtmek gerekiyor. Şöyle ki, hukuk fakültelerinde eğitim "takrir usulü" (anlatma/ders verme) ile verilir. Pratik çalışmalar varsayımsal olaylar üzerine kuruludur. Üstelik hâlâ, pratik çalışmaların yapılıp yapılmaması, dersi veren öğretim üyesinin takdirindedir. Bunun dışında 1940'larda hukuk eğitiminin anlatıma/ders vermeye dayalı olması anlaş11ırdır. Her şeyden önce bilgiye erişimin kısıtlı olduğu bir dönemden bahsediyoruz. Bu halde, öğrencilere mevzuatın ve birtakım ilkelerin "belletilmesi” gerekiyordu. Çünkü bu öğrenciler, mezuniyetlerinden sonra ülkenin çeşitli yerlerine gidecekler, hakim/savcı veya avukat olacaklar ve önemli kararlara imza atacaklardı. Ne kadar çok şey bilirlerse, o kadar iyi

\footnotetext{
${ }^{28}$ ANSAY, s. 264.

29 ANSAY, s. 268.

30 ANSAY, s. 307.

31 LONBAY ve TOPRAK, s. 215.
} 
kararlar verebilirlerdi. Yani buradaki motivasyon, kısa sürede olabildiğince çok bilgiyi öğrenciye vermekti. Bunun yolu da, kısıtlı ders kitaplarını ve yazılı kaynakları hesaba katarsak, konuyu "belletmekten" geçiyordu. Peki bu yöntemin şimdiki zamanda karşılığı nedir? Küreselleşmenin hukuk mesleğine ve hukuk eğitimine yansımalarının olması kaçınılmazdır. ${ }^{32}$ Bilgiye erişim kaynaklarının değişmesi, çeşitlenmesi de, bilgiye erişimde algı değişikliği yaratmıştır. Oysa hukuk fakültesini kazanan öğrencilere söylenen iki şey vardır, "o kadar şeyi nasıl ezberleyeceksin?" ve "o kadar kalın kitapları nasıl okuyacaksın?". Hukuk eğitiminin ezbere dayalı olmasına dair alg1, eğitimin tekniğinden kaynaklanmaktadır.

Yükseköğretim sisteminden kaynaklanan sorunlar da, Türkye'de hukuk eğitiminin kalitesini etkilemektedir. Örneğin büyük devlet üniversitelerindeki 600-1000 kişilik devasa kontenjanlar, asgari eğitici kadrosuna sahip olmayan fakültelere kontenjan verilmesi, ikinci öğretim sistemi, hukuk eğitiminde beklenen sonuçlara erişmeyi zorlaştırmaktadır. ${ }^{33}$ Türkiye'de hukuk fakültesindeki kontenjan artışı çok çarpıcıdır. 2010 yılında devlet üniversiteleri kontenjanı 5930, vakıf üniversiteleri kontenjanı 2780, toplam kontenjan 8710 iken, yedi yıl sonra 2017 yılında devlet üniversitesi kontenjanları \%81 artışla 10731, vakıf üniversiteleri kontanjanları \%104 artışla 5689 olmuştur. Toplam kontenjan 16420'ye varmış ve artış oran1 \% 89 olarak gerçekleşmiştir. ${ }^{34}$ Hukuk fakültelerinde zorunlu olarak yığın eğitimi yapılmakta, bu da ezbere dayalı sistemden, takrir usulünden vazgeçmeyi zorlaştıran bir unsur olmaktadır. Böylesi bir durumda pratik çalışmalardan beklenen verimin alınması da zordur. Öğrencilerin çoğu, kitap veya hoca yüzü görmeden, derslere katılmadan mezun olmaktadır. Bırakalım etik davranışların benimsenmesini, ortalama bir tartışma, fikirlerin muhakeme edileceği bir alandan dahi yoksundurlar. Yılda birkaç kere girilen sınavlarla bilgi ölçme sistemi de, bilgiye erişim süreçlerindeki problemler sebebiyle, ezberci eğitim modelinin devamı niteliğinde olmaktadır. Takrir yöntemi yalnızca Türkiye'ye özgü bir model değildir. Yukarıda bahsedildiği şekilde, belirli kitaplardaki ve eskiden gelme hukuki bilgilerin tekrar edilmesi, böylece hukuk öğrencisinin eğitilmesi $A B D$ ve Avrupa'da da en yaygın yöntemdi. Bu noktada hukuk eğitiminin ne hedeflediğinden söz etmek gerekir.

\footnotetext{
32 GÖZLER, s. 3021-30.

33 ERKUT, s. 7-8.

34 ERKUT, s. 6.
} 
Hukuk fakültesinden mezun olduktan sonra, yapılacak işe göre meslek içi eğitim alınır. Avukatlık için bir yıllık baro stajı, hakimlik/savcılık için kural olarak iki yıllık meslek içi eğitimde, mesleğin detayları, meslek ilkeleri ve etik ilkeler meslek adayına aktarılır. Bu bağlamda, hukuk eğitiminin meslek eğitimine hazırlık olarak görüldüğü söylenebilir. Ancak meslek eğitimi ile hukuk eğitimi birbirinden farklıdır. Bu noktada hukuk eğitiminin, mezunlara kazandırması beklenilen bazı beceriler ve değerler vardır. Hamide Topçuoğlu, hukukçunun, hukuku yalnız uygulamaması gerektiğini, aynı zamanda sebepleri, sonuçları, amaçları ve işlevleriyle bilmesi gerektiğini belirtir. Böylece "hukukçular, başını ve sonunu karıştırmaya mezun olmadıkları bir kitabı okur gibi, sırf mevzu hukuk normlarının muhtevalarını tetkike mahkûm olmaktan ancak bu sayede kurtulabilmişlerdir." ${ }^{35}$ Kanun koyucunun üç yeni düzeltici kelimesiyle koca kütüphaneler okkalık kağıt haline gelebileceğinden ${ }^{36}$, hukukçular, mevzu hukukun ötesine odaklanmış bir eğitimle, muhakeme yapabilir, etik değerleri içselleştirebilir hale gelebilirler. Böylece "adil kişiliği ortaya çıkarıcı ve adalet talep eden, adalet arayan hukukçunun inşası" ${ }^{37}$ mümkün olabilir ve hukukçular adaletin sağlanmasına katkı sunabilirler.

Hukuk eğitiminde geliştirilmesi gereken değerler ve yetilerin başında "hukukçu gibi düşünmek" gelir. Burada öğrencilerin mevcut bir uyuşmazlıkla ilgili olguları inceleme, hukukla ilişkilendirme, hukuk dilinde ifade etme ve hukuki çözüm bulmayı içerir. Ancak bu işin yalnızca "teknik kısmıdır" ve hukuk öğrencilerinin teknik becerilerinin geliştirilmesi yanında insani yönlerinin de geliştirilmesi gerekir. $\mathrm{Bu}$ noktada belirli etik değerlerin hukukçulara kazandırılması gerekecektir. ${ }^{38}$ Hukukun insana dair bir meşgale olduğu gerçeği, salt teknik hukuk bilgisinin, hukuki uyuşmazlığı adalete uygun şekilde çözmeye yetmeyeceğine işaret eder. Yasaların lafzının ve uygulamasının sorgulanması, iyileştirilmesi ve hukukun kapasitesinin zorlanması, hukukçular için bir hedef olmalıdır ki, hukukçular bir teknikerden, yalnız kuralları uygulayan "makineler" olmaktan kurtulabilsinler. Bunun yolu da etik değerlerin benimsenmesinden geçer.

Dolayısıyla, meslek içi eğitimden farklı olarak, (ki meslek içi eğitim hem pratiğe hem de meslek etiği ilkelerine yönelik bir eğitimdir ${ }^{39}$,) hukuk

\footnotetext{
35 TOPÇUOĞLU, s. 6.

36 V. KRICHMANN, s. 198.

37 IŞIKTAÇ, s. 281.

38 UYGUR (2008), s. 167-68.

39 Hukuk fakültesi öğrencileri arasında, özellikle son sınıflarda, bir avukatın yanında çalışmak
} 
fakültesinde verilen eğitimin de hedefleri olmalıdır. Staj bir meslek içi eğitim vazifesi gördügünden ${ }^{40}$, staj öncesi bir hazırlık aşaması, hukuk eğitimidir.

Hukuk öğrencilerinin geliştirilmesi gereken yetileri ve bunlarla ilişkili değerleri bağlamında, üç yeti ön plana çıkmaktadır: sokratik sorgulama, dünya vatandaşlığı ve empati. Sokratik sorgulama yetisi, hukukçunun önüne gelen kuralları sadece otorite bunlar emrettiği için ve alışkanlık sebebiyle değil, haklı gösterme ve tutarlılık süzgecinden geçirerek benimsemeyi içerir. Öğrencilerin kendilerini insanlığın bir üyesi veya insanlığa ait olarak görebilmeleri, dünya vatandaşlı̆̆ 1 yetisidir. Kendisinden farklı insanlar gibi düşünebilmek, karşısındaki kişinin duygularını, isteklerini anlayabilmek ise empati yetisine tekabül eder. ${ }^{41} \mathrm{Bu}$ yetilerin geliştirilmesi, salt bir teknik bilgi aktarımına indirgenemez. Hukuk eğitimindeki bu hedeflerin, hukukun yöneldiği adalet değerinin içeriği tartışmalı ve farklı olsa da, ortaklaşması sebebiyle evrensel olduğu söylenebilir. Amerikan Barolar Birliği'nin 1992 y1lında hazırladığı rapora dayanan ve hemen her ülke için geçerli olabilecek beceri ve değerler, ayrıntılı olarak şu şekilde sıralanmıştır:42

Beceriler:

1. Hukuki problemi doğru teşhis etme ve farklı çözümlere yönelik strateji belirleme,

2. Hukuki analiz, muhakeme ve gerekçelendirme,

3. Kurallara, kurumlara ve kavramlara ulaşma konusunda araştırma,

4. Maddi vakıalara ilişkin iyi soruştuma yapma ve elde ettiği bilgiyi iyi değerlendirme,

5. Sözlü ve yazılı iletişim, özellikle hukuki kavramları farklı alg1 düzeylerindeki sıradan insanlara açık bir şekilde aktarabilme,

6. İyi danışmanlık hizmeti verebilme,

\footnotetext{
yaygındır. Ancak burada denetim olmadığından, öğrenciler ciddi bir emek sömürüsü ile karşı karşıya kalabilmektedirler. Meslek içi eğitim açısından da, staj eğitiminin tek tip ve yeknesak olmaması, özellikle avukatlık stajlarının içeriğinin baro inisiyatifinde düzenlenmesi, ya da ikinci altı aylık avukat yanı stajının etkili olmaması gibi durumlar neticesinde, "fason stajlar" yapilabilmektedir.

40 YÜRÜK.

${ }^{41}$ UYGUR (2008), s. 169-70.

42 YÜRÜK.
} 
7. Etkili müzakere yöntemlerini kullanma,

8. Hukuki sorunun çözümüne ilişkin süreci iyi organize etme,

9. Alternatif uyuşmazlık çözüm yollarında etkin olma,

10. Etik sorunları belirleme ve doğru çözüm üretme.

Değerler:

1. Liyakatli temsil,

2. Adalet, hakkaniyet ve ahlak için mücadele etmek,

3. Mesleği geliştirmek için çaba göstermek,

4. Mesleki kişisel gelişimi gerçekleştirmek.

Öğrenciler, gerçek problemlerle karşılaştıklarında ister istemez etik konularla yüzyüze gelirler. karşılaşırlar. Ve bunları analiz edip doğru davranışı sergilemek konusunda öğrencileri hazırlamak gerekir. Farklı klinik çalışmalarının farklı çıtılları olacaktır elbette. Ama belirli standartları hedeflemek gerekiyor: Gizlilik ile ilgili kurallar; akıl yürütme becerisi (yani alternatif hareket tarzlarını geliştirebilmek ve bunları değerlendirebilmek -ahlaki muhakeme- için kural ve kanunların nasıl uygulanacağı konusunda akıl yürütme kabiliyetine sahip olunmalıdır) ve profesyonel kimlik, yüreklilik, kararlılık, yaratıcı sorun çözme becerilerinin geliştirilmesi. ${ }^{43}$

$\mathrm{Bu}$ noktada klinikler, hukuk fakültesi öğrencilerinin okulda teorik olarak öğrendikleri kavram ve kuralları gerçek hayatta uygulamaya yönelik olarak gerekli becerileri edindikleri bir öğretim yöntemi veya öğrenim süreci olarak tanımlanır. ${ }^{44}$ Yukarıda belirtilen beceri ve değerlere yalnızca takrire dayalı bir eğitimle ulaşılamayacağı bir gerçektir. Pratik çalışmalar ise, öğrencilerin muhakeme becerilerinin vb. gelişmesi beklentilerini karşılamaya yetmemektedir. ${ }^{45}$ Buna öğrencilerin lise eğitimleri ve altyapıları eklenince,

43 AZAPAĞASI et al., Leah Wortham sempozyum konuşması, s. 81 vd.

${ }^{44}$ YÜRÜK

45 A ve B arasındaki hukuki olay sonucu ortaya çıkan cezai ya da hukuki sorumluluğun irdelenmesine ilişkin pratik çalışmalar, olayı kavramsallaştırma, hukuki ilişkiyi tarifleme vb açılardan elbette faydalıdır. Ancak örneğin A, avukatken sizin karşınıza geldiğinde kanlı canlı bir insandır. Size durumu bu kadar açık bir şekilde ifade edemeyebilir. Ya da travma sonrası stres bozukluğu yaşıyordur ve sadece ağlıyordur. Sizin olayı karşı tarafa anlattırmanız, hukuki olarak sınıflandırmanız, yol göstermeniz gerekir. Bir insana bir bilgiyi doğru ve onun anlayacağı şekilde iletmenin sorumluluğunu üstlenirsiniz gerçek insanlar 
donanımlı hukukçular yetiştirmek için hukuk eğitiminde alternatif metotlar Türk hukuku eğitimi veren fakülteler için de gündeme gelmiştir.

\section{TÜRKIYYE'DE HUKUK KLIINIKLERİ UYGULAMALARI}

Eğitimde pratiğin eksikliği her zaman dile getirilen bir sıkıntıdır. ${ }^{46}$ Çoğu hukuk öğrencisi, dava dosyası görmez, yine bir çoğu mezun olduktan sonra adli sicil belgesi almaya adliyeye gitmiştir. Elbette ki hukuk yaşam alanının farkında olanlar, ailesinde hukukçu olanlar vardır ama bunlar azdır ve genel eğitimde yaşayan uygulama eksikliğini giderecek oranda değildir.

Türkiye'de de pek çok hukuk fakültesinde hukuk kliniği çalışmaları başlamıştır ve sürmektedir. Burada öne çıkan üç klinik çalışmasının genel hatlarından bahsedeceğim. ${ }^{47}$ Bilgi Üniversitesi hukuk fakültesi kliniği, Türkiye'de kurulan ilk hukuk kliniği olma özelliğini taşımaktadır. Turgut Tarhanlı, öğrencilerin sınıf gibi korunaklı ve yapay bir ortamda değil, bizzat yaşayarak öğrenmesini sağlamamayı amaçladıklarını belirtmektedir. ${ }^{48}$ Bilgi Üniversitesi bünyesinde iki tip klinik vardır. İlki "gündelik hayatta hukuk kliniği" denilen ve esasında "street law" modeline dayanan kliniktir. Bu klinik faaliyetleri çerçevesinde, hedef gruplara sahip oldukları haklar ve temel hukuk bilgisi eğitimi verilmiştir. İlköğretim 8. Sınıf öğrencileri ile başlayan eğitimler, ceza infaz kurumlarında bulunan hükümlülerle devam etmiştir. Aynı kapsamda özellikle dar gelirli ve yoksul insanlarla çalışan sivil toplum örgütlerinin personeline de temel hukuk bilgisi eğitimleri verilmiş. Diğer klinik çalışması uygulamalı hukuk kliniğidir. Burada hukuki yardım alma ve hukuki bilgiye erişme imkanları kısıtlı kişilere hukuki bilgi verilmektedir. Öğrenciler bu klinikte, kliniğe başvuran kişiyle mülakat yapmakta, vakayı öğrenmekte, kayda geçirmekte, hukuki sorunu tespit etmekte, vaka üzerinde hukuki araştırma yapmakta, yazılı görüş hazırlamaktadır. Yazılı görüş, dersi veren öğretim üyesi tarafından incelendikten sonra ilgili kişiye ulaştırılmaktadır. Genelde aile hukuku, iş ve sosyal güvenlik hukuku, borçlar hukuku ve tüketici hukuku konularında hukuki görüş verildiği belirtilmiştir.

söz konusu olduğunda. Dolayısıyla mesele sadece bilmek değil, bunu doğru, eksiksiz ve anlaşılır şekilde karşı tarafa iletmek ve sorunu çözmektir.

461969 ve 2010 tarihli iki eserde odak konuların benzerliği dikkat çekicidir. ANSAY; ÖZTOPRAK SAĞIR.

47 Belirtilen klinik çalışmalarında dair bilgiler, derli toplu bilgi sunması ve yeni tarihli olması sebebiyle Uluslararası Hukuk Klinikleri Sempozyumu'ndaki sunuşlardan alınmıştır. AZAPAĞASI et al.

48 AZAPAĞASI et al., Turgut Tarhanlı sempozyum konuşması, s. 136-49. 
Anadolu Üniversitesi Hukuk Fakültesi Hukuk Kliniği, öğrenciyi uygulamanın içine yerleştirme odaklı, öğrencinin uygulamadan iyi şekilde bilgilenmesini sağlamayı amaçlayan bir çalışma olarak tanımlanmaktadır. ${ }^{49}$ Bu bağlamda farklı klinikler açılmıştır. Gündelik hayatta hukuk kliniği, yurttaş kliniği, toplumsal cinsiyet, tüketici hakları, borçlar hukuku, uluslararası hukuk, arabuluculuk, çocuk suçluluğu ve adaleti, adli yazışma, cezaevi projesi gibi klinikleri mevcuttur. Örneğin Anadolu Üniversitesi'ne Erasmus program1 ile gelen pek çok yabancı öğrencinin varlığı ve bu öğrencilerin bir şekilde hukuki sorunlarla temas etmeleri (ev kiralama, elektrik su abonelikleri ve benzeri) sonucu, yabancı öğrencilere yönelik bir klinik çalışması yapılmıştır. Bu klinikte, beş farklı dilde Türk Hukuku'nu anlatan bir broşür yazılmış ve bir danışma birimi kurulmuştur. Bu birimde yabancı öğrencilerin sorunları ile birebir ilgilenilmektedir. Yine flört şiddetinin üniversite öğrencileri arasında çok yaygın olduğu tespitiyle, flört şiddetine dair broşür hazırlanmış ve dağıtılmıştır. Öğrencilerin talebiyle çocuk adaleti (juvenile justice) konusunda bir yasa metni hazırlanmıştır. Bu klinik bir yasama kliniği örneğidir. Öğrenciler önce çocuk suçluluğuna ilişkin mevzuatı taramış, diğer ülke örneklerini incelemişlerdir. Daha sonra baro ile, hakimler, savcılar, polisler ve STK'larla çocuk koruma konusunda görüşmüşler, araştırma ve inceleme yapmışlar, bunları raporlamışlar ve ilgili mercilere sunmuşlardır.

Ankara Üniversitesi Hukuk Fakültesi klinik çalışması ise üç aşamalı bir çalışmadır. ${ }^{50}$ Öğrenciler 2., 3., ve 4 . sınıfta bu klinik çalışmasına dahil olmaktadır. Birinci aşamada temel kavramlar ve mevzuat bilgisine dayalı teorik düzeyde bir çalışma yürütülmektedir. Hukuk ve etik, meslek etikleri, toplumsal cinsiyet, hukuk ve edebiyat gibi dersleri alan öğrenciler, klinik çalışması için teorik bir temele sahip olmaktadır. İkinci aşamada öğrenciler zorunlu olan hukuk felsefesi ve sosyolojisi derslerini alıp, yanında hukuk ve edebiyat, aile mahkemeleri, kadın hakları ve hukuka felsefeyle bakmak adlı farklı grup çalışmalarına katılmaktadır. Bu grup çalışmaları genellikle gündelik hayatta hukuk/street law prensibiyle işlemektedir. Üçüncü aşama ise hukuk klinikleridir. Farklı hukuk klinikleri farklı çalışmalar yürütmektedir. Bireysel başvuru, engelliler, ev içi şiddet, fikri haklar, hapishaneler, hasta hakları, kentsel dönüşüm, mülteciler, Türkiye'de işçi olmak ve toplumsal cinsiyet klinikleri mevcuttur. Örneğin hapishaneler kliniği kadın cezaevini ziyaret edip kadın hükümlülerin hukuki problemleriyle ilgilenmektedir.

\footnotetext{
49 AZAPAĞASI et al., Ufuk Aydın sempozyum konuşması, s. 161-71.

50 AZAPAĞASI et al., Gülriz Uygur sempozyum konuşmas1, s. 125-34.
} 
Üç yıllık programa dahil olan öğrenciler bir sertifika almaktadır. Ankara Üniversitesi'ndeki klinik uygulamasının diğerlerinden ayrılan bir yönünün, klinik çalışmasında da özellikle vurgulanan bir konu olduğu söylenebilir: öğrencilere etik farkındalık kazandırmak. Hukuk öğrencisi, somut olayı yorumlarken adaletsizliği görebilmelidir. Adaletsizliği görmenin önünde çeşitli engeller vardır, önyargılar, mantık hataları ve klişeler gibi. İşte hukukçuların belirli erdemlere sahip olması gerektiğini öngören bu klinik çalışmasında, erdemlerin, Aristoteles'e atıfla yapa yapa öğrenileceği kabul edilir. Hukukçular için hukuki akıl yürütmede ilk iş keşfetmek, ikincisi ise adaleti gerçekleştirmeyi istemektir. Bunun için de hukukçu "dertlenerek ilgilenmelidir". Yani yalnızca adaletsizliği görmek yetmez, adaletsizliği giderici şekilde çözüm bulmak da gerekir ${ }^{51}$. Ankara Üniversitesi Hukuk Fakültesi klinik çalışması adaletsizliği görmek ve dertlenerek ilgilenmek prensipleri üzerinden aşamalı bir çalışma yürütmektedir.

Belirtilenler dışında Türkiye'de pek çok fakültede irili ufaklı klinik çalışmaları yürütülmektedir. Özellikle barolarla yapılan işbirlikleri yaygındır. Her birini tek tek incelemek ve eğitim çıktılarını tespit etmek bu çalışmanın kapsamını aşacağından önemli örneklere yer verilmiştir.

Klinik çalışmaları hukuk eğitiminde popüler konu başlıklarından biri olsa da, uygulamada en büyük aksaklıklardan biri kalabalık öğrenci topluluklarında, klinik çalışmasına katılabilecek ya da çalışmanın etki edebildiği öğrenci sayısının azlığıdır. Ayrıca, avukatlar cephesinden de klinik çalışmalarına olumsuz tepkiler vardır. Bağlantılı şekilde, hukuk kliniklerinin yasal statüsünün olmaması ve mevcut yasal düzenlemelere aykırı olarak yorumlanabilen faaliyetleri nedeniyle, olumsuz görüşler mevcuttur. Avukatlık Kanunu'nun 35. Maddesine göre “(...) kanun işlerinde ve hukuki meselelerde mütalaa vermek, mahkeme, hakem veya yargi yetkisini haiz bulunan diğer organlar huzurunda gerçek ve tüzel kişilere ait haklar dava etmek ve savunmak, adli işlemleri takip etmek, bu işlere ait bütün evrakı düzenlemek, yalnız baroda yazll avukatlara aittir”. Kliniklerin, haksız rekabet teşkil edebilecek faaliyetler gerçekleştiren rakip kurumlar olarak görülmesi söz konusudur. Bu hüküm esas alınarak, kliniğe gelen gerçek kişilere hukuki problemler hakkında görüş vermenin avukatlık tekeline aykırılık anlamına geldiği gerekçesiyle klinik çalışmaları eleştirilmektedir. Bir başka husus, avukatlık mesleğinin kamu hizmeti yönü ve meslek sırrı gibi özel kuralları

${ }^{1}$ UYGUR (2013), Gülriz Uygur bu eserinde, hukukta adaletsizliğin nasıl görülebileceğini ve adaleti gerçekleştirmeyi istemenin somut adımlarını ayrıntılı şekilde anlatmaktadır. 
olan bir meslek olmasıdır. Hukuk fakültelerinde kişilere verilecek hizmetin meslek sırrı başta olmak üzere avukatlık meslek ilkeleriyle bağdaşmayan unsurları, disiplin hukukunu ilgilendiren yönleri olabilir. ${ }^{52}$ Hukuk kliniklerine karş1 avukatlar cephesinden gelen eleştirilere, özellikle disiplin hukuku ve meslek ilkeleri bağlamında kulak vermek gerekir. Gizlilik, meslek sırrı gibi konulara dikkat edildiği ve öğrenciler bu süreçlerde tek başına bırakılmadığ 1 ve her aşamanın profesyoneller tarafından denetlendiği bir uygulama sağlıklı olacaktır. Yine de klinik çalışmalarının, hukuk eğitiminde bu şekilde gündeme gelmesi ve kurumsallaşma konusunda ciddi adımlar atılması, geleceğe dair umut vericidir.

\section{KUZEY KIBRIS'TA HUKUK KLİNIKLERİ: NE YAPILABİLİR?}

Kuzey Kıbrıs Türk Cumhuriyeti'nin (KKTC) köklü ve karmaşık tarihi, hukuk sistemine de yansımıştır ve KKTC hukukunun esas olarak Anglo-Sakson hukukuna dayanan, fakat ülkenin şartlarına uydurulmuş bir hukuk mozayiği olduğu belirtilmektedir. ${ }^{53}$ KKTC'de hali hazırda 10 hukuk fakültesi ${ }^{54}$ vardır. Bu fakültelerde 1000 'den fazla öğrenci eğitim görmektedir. Hukuk fakültelerinde verilen eğitim Türk hukukudur. Kıbrıslı öğrenciler ise Kıbrıs hukukuna dair dersler alarak, KKTC'de hukuk mesleklerini icra edebilmektedirler.

KKTC'de hukuk kliniği yürütmek ilk bakışta dezavantajlı görünebilir. Mahkeme ziyareti ve benzeri gibi, doğrudan hukuk uygulamasına yönelik çalışmaların karşılıksız kalacağı intibaı oluşabilir. Her şeyden önce klinik çalışması, yalnızca mahkeme ziyareti ya da adliye pratiğine indirgenemeyecek bir modeldir. Önemli olan öğrencilerin etik farkındalık kazanması, adaleti tesis etme noktasında erdem sahibi olmaları ve güven geliştirmeleri, hukuki problem çözme becerilerinin gelişmesidir. Bu noktada bu hibrid hukuk sisteminin avantajlı olduğu düşünülebilir. ${ }^{55}$ Çünkü öğrenciler farklı bir hukuk uygulamasına şahit olurlar ve bu da hukuk kültürü açısından ufuklarını açma potansiyeline sahiptir. Bunun dışında yasama klinikleri uygulaması her

\footnotetext{
52 ÖZTOPRAK SAĞIR, s. 77-79.

53 TURHAN, s. 281.

54 Yükseköğretim Kurulu.

55 ERGINEL, s. 9. Taner Erginel, KKTC'nin iki hukuk sistemi açısından bakıldığında son derece ilginç bir konumda olduğunu, bu konumun avantajının dünyada uygulanan iki hukuk sisteminden birini uygularken, diğerini de tanıma olanağına sahip olmasından kaynaklandığını belirtir.
} 
durumda yapılabilir. Türk hukukuna dair her konu hakkında yasa yapım ya da yasa değerlendirme çalışmaları, ilgili konunun anlaşılması, yorumlanması bakımından ve hukuk metodolojisi açısından oldukça etkili bir öğrenme ortamı sağlayabilir. Ayrıca birtakım konular hukuk sistemleri ayrımını aşar; mültecilerin durumu, toplumsal cinsiyet eşitsizliği, çocuk hakları gibi. $\mathrm{Bu}$ konularda öğrenciler gündelik hayatta hukuk kliniği çalışması yapabilirler. Yani belirli konularda araştırma ve görüşmeler yapıp, ilgili topluluklara öğrendiklerini anlatabilirler. Hukuk edebiyat kliniği, edebi metinler üzerinden hukuku görmeyi ve tartışmayı amaçlar. Ayrıca belirli gruplara yönelik çeşitli broşür çalışmaları yapılabilir. Bu sayede öğrenciler kültürel farklılıkların farkında olmayı öğrenip, empati yetilerini geliştirebilirler. $\mathrm{Bu}$ da, kendi kültürel, sosyal geçmişlerinden farklı sosyalliklere sahip müvekkillerle daha iyi çalışmalarına yardımcı olabilir. Araştırma ve tartışma, muhakeme becerilerini artırabilirler. Çok kültürlü yapısıyla KKTC'de dünyanın çok farklı yerlerinden insanlarla, öğrencilerle temas eden hukuk öğrencisi, vizyonunu da geliştirebilir. Öğrencileri pratikle buluşturmayı istedikten ve hukuk eğitiminde öğrencilere belirli beceri ve değerleri kazandırmak amacında olduktan sonra sınırların ya da hangi hukuk sisteminin uygulandığının çok da önemi olmayacaktır. Ayrıca hukuk fakültelerindeki öğrenci sayısı, özellikle Tükiye'deki devlet üniversiteleriyle karşılaş̧ırıldığında azdır. Bu da, öğrencilerle birebir çalışmalar yapmayı kolaylaştırmaktadır.

\section{SONUÇ}

Hukuk kliniklerinin heryerdeve herdurumda aynışekildeuygulanabilecek bir formül olmadığını daha önce belirtmiştim. Farklı ihtiyaçlar, farklı klinik modellerinin oluşumuna sebep olmuştur. Tekrar vurgulamak gerekir ki, klinik ihtiyac1, mevcut eğitim modelinin eksikliklerine bir cevap olarak ortaya çıkmıştır. Kliniklerin bugünkü yaygınlığı ve popülerliği, değişen dünyaya, değişen hukuk ve adalet algısına, bu değişimin yarattı̆̆ ihtiyaca tekabül edebilmesindendir. Eğer, hukuk eğitimini ve adalete erişimi, hakkında konuşulduğu kadar etkileyebilirse, ihtiyaçlara yanıt verebildiği ölçüde eskiyecek ve yenilenecektir. Bu, konu edindiği hukukun, toplumsal gelişmeleri takip etme özelliğinden kaynaklanmaktadır. Türkiye'de hukuk kliniklerinin uygulanması kısmında, hukuk kliniklerinin kısıtlarına değinilmiştir. Mevcut kısıtlarına rağmen, klinik modelinin, hukuk eğitimindeki krizi azaltmak ve belki de çözmek yolunda önemli bir adım olduğu söylenebilir. Elbette tek başına yeterli olması mümkün değildir. Hukuk uygulaması da, hukuk eğitimi de, çok boyutlu ve çok taraflı süreçlerdir. Dolayısıyla hukuk kliniklerinin tek 
başına eğitim modelinde bir devrim yaratması ya da dezavantajlı grupların adalete erişim sürecindeki problemleri çözmesi olanaklı değildir. Yine de, düzgün, prensiplere bağlı bir şekilde işleyen bir hukuk kliniği çalışması, her öğrencide bir bilinç yaratabilir. Adaleti değerlendirebilen, muhakeme becerisine sahip, grup çalışmasını bilen, etik ilkelerden haberdar ve onları aktif şekilde uygulama sorumluluğu almış, hukukun yöneldiği adaleti ve diğer değerleri yaşamında gerçekleştirmeye niyetli bir çok hukukçu adayının hal ve hareketlerinin adalet mekanizmalarına olumlu yansıyacağı da aşikardır.

Türkiye'de hukuk eğitiminin mevcut sorunlarını çözmek için de kıymetli bir alternatif öğrenme metodu olan hukuk klinikleri, Türkiye hukuk fakültelerinde yaygınlaşmaktadır. KKTC'nin hukuksal yapısı ve sosyal karakteri ise, hukuk öğrencileri için, bir klinik çalışmasından umulan potansiyel faydayı artırıcı unsurlar olarak değerlendirilebilir.

\section{KAYNAKÇA}

Adalet Bakanlığı, Adalet Bakanlığı Stratejik Planı (20152019 ). (http://www.adalet.gov.tr/stratejikplan/adalet Bakanl\%C4\%B1\%C4\%9F\%C4\%B1StratejikPlan\%C4\%B12010-2014. pdf., erişim 17.01.2019)

Adalet Bakanlığı, Adalet Bakanlığı Yargı Reformu Stratejisi 2015. (http:// www.sgb.adalet.gov.tr/yargi_reformu_stratejisi.pdf., erişim 17.01.2019)

AKÇAOĞLU, Ertuğrul: “Ankara Üniversitesi Hukuk Fakültesi’nin Kuruluşu ve İlk Günleri." Türkiye Barolar Birliği Dergisi, C. 21, S. 80, OcakŞubat 2009, s. 367-79.

ANSAY, Tuğrul: "Hukuk Eğitiminde Reform (Bir Deneme)." Ankara Üniversitesi Hukuk Fakültesi Dergisi, C. 26, S. 1-2, 1969, s. 261-321.

AZAPAĞASI, Alpaslan/ İNAN, Kubilay/ YILMAZ, Jale/ TOKAR GÜNEŞ, Zuhal (editörler): Uluslararası Hukuk Klinikleri Sempozyumu, Adalet Bakanlığı Strateji Geliştirme Başkanlığı, Ankara, 2017.

BLOCH, Frank S./ MENON, N.R. Madhava: "The Global Clinical Movement.", The Global Clinical Movement- Educating Lawyers for Social Justice, ed. BLOCH, Frank S., New York, Oxford University Press, 2011, s. 267-277. 
BLOCH, Frank S./ NOONE, Mary Anne: "Legal Aid Origins of Clinical Legal Education", The Global Clinical Movement- Educating Lawyers for Social Justice, ed. BLOCH, Frank S., Oxford University Press, 2011, s. 153-166.

CAN, Cahit: Hukuk Sosyolojisinin Antropolojik Temelleri ve Genel Gelişim Çizgisi, 3. bask1, Siyasal Kitabevi, Ankara, 2011.

CAPPELLETTI, Mauro/ GARTH, Bryant: "Access to Justice: The Newest Wave in the Worldwide Movement to Make Rights Effective", Buffalo Law Review, C. 27, s. 181-292.

CHODOSH, Hiram: "Hukuk Eğitimi: Trendler, Sorunlar ve Stratejiler", Selçuk Üniversitesi Hukuk Fakültesi Dergisi, C. 9, S. 1-2, 2001, s. 327-36.

D’AMELIO, Mariano: "Hukuk Kliniği”, İstanbul Üniversitesi Hukuk Fakültesi Mecmuası, S. 2, 1936, s. 70-74.

EDGEWORTH, Brendan: Law, Modernity, Postmodernity: Legal Change in the Contracting State, Ashgate, 2003.

ERGINEL, Taner: Kusursuz Yargı Oluşturma Çabaları. Okman Printing Ltd., 2017.

ERKUT, Erhan: Yükseköğretimde Kontenjan Balonu, Ocak 2019. (http:// erhanerkut.com/wp-content/uploads/2019/01/KontenjanBalonu.pdf., erişim 21.01.2019)

FRANK, Jerome: "Why Not a Clinical Lawyer-School?", University of Pennsylvania Law Review and American Law Register, C. 81, S. 8, 1933, s. 907-23.

GÖZLER, Kemal: "Küreselleşme Sürecinde Hukuk Eğitimi”, Legal Hukuk Dergisi, C. 6, S. 69, Eylül 2008, s. 3021-30.

GRIMES, Richard: “Accessing Justice: The Role of Law School Legal Clinics in Conflict-Affected Societies", Asian Journal of Legal Education, C. 1, S. 2, 2014, s. 71-87.

HİRSCH, Ernst E: Anılarım/ Kayzer Dönemi, Weimar Cumhuriyeti, Atatürk Ülkesi, 13. bask1, Tübitak Yayınları, Ankara, 2017. 
HOWARD, Emma: "Legal Aid Cuts: 'The Forgotten Pillar of the Welfare State' - a Special Report", The Guardian, 25 Eylül 2014. (http:// www.theguardian.com/law/2014/sep/25/-sp-legal-aid-forgotten-pillarwelfare-state-special-report-impact-cuts., erişim 19.01.2019)

IŞIKTAÇ, Yasemin: "Hukuk Öğretim ve Eğitiminde Etiğin Yeri.” Uluslararası Yargı Etiği Sempozyumu, Adalet Bakanlığı Strateji Geliştirme Başkanlığı, Ankara, 2016.

KAHN-FREUND, Otto: "Reflections on Legal Education", The Modern Law Review, C. 29, S. 2, 1966, s. 121-86.

LONBAY, Julian/ TOPRAK, Musa: "Legal Clinics in Turkey", Clinical Legal Education in Asia/ Accessing Justice for the Underprivilege, ed. PROSUN SARKER, Shuvro, New York, Palgrave Macmillan, 2015, s. $215-227$.

MACDONALD, Roderick A.: "Access to Justice in Canada Today- Scope, Scale, Ambitions", Access to Justice for a New Century: The Way Forward, ed. BASS et al., The Law Society of Upper Canada, 2004, s. $19-112$.

McQUOID, David: "The History and Purpose of the Clinical Legal Education/ Hukuk Kliniği Öğretiminin Tarihçesi ve Amacı”, Hukuk Öğretiminde Yeni Yaklaşımlar: Hukuk Klinikleri Uluslararası Sempozyum, ed. AKBAŞ, Kasım/ İNCE, Asuman, Anadolu Üniversitesi Yayını, Eskişehir, 2013, s. $10-31$.

MINOW, Martha: "Marking 200 Years of Legal Education: Traditions of Change, Reasoned Debate, and Finding Differences and Commonalities", Harvard Law Review, C. 130, S. 9, 2017, s. 2279-2297.

ÖZTOPRAK SAĞIR, Meral: Güncel Gelişmeler Ișığında Türkiye'de Hukuk Eğitimi, Türkiye Barolar Birliği, Ankara, 2010.

TOPÇUOĞLU, Hamide: Hukuk Sosyolojisi, 3. bask1, Ankara Üniversitesi Hukuk Fakültesi Yayınları, Ankara, 1969.

TURHAN, Turgut: "Tarihsel Bakış Açısıyla Kıbrıs Türk Hukuk Sistemi", Ankara Üniversitesi Hukuk Fakültesi Dergisi, C. 57, S. 2, 2008, s. 253-86.

UYGUR, Gülriz: "Hukuk Eğitiminde Geliştirilmesi Gereken Yetiler, Hukuk 
Felsefesi Öğretimi ve Alternatif Metotlar", Hukuk Felsefesi ve Sosyolojisi Arkivi 18, İstanbul Barosu Yayınları, İstanbul, 2008, s. 166176.

UYGUR, Gülriz: Hukukta Adaletsizliği Görmek, Türkiye Felsefe Kurumu, Ankara, 2013.

V. KRICHMANN, Julius Hermann: "İlim Olmak Bakımından Hukukun Değersizliğii”, Ankara Üniversitesi Hukuk Fakültesi Dergisi, C. 6, S. 1, 1949, s. 181-212.

WILSON, Richard J.: "Gelişmekte Olan ve Yeni Demokratikleşen Ülkelerde Adaletin Sağlanmasını Geliştirmede Araç Olarak Uygulamalı Hukuk Eğitimi”, Ankara Barosu Dergisi, S. 3, 1997, s. 79-94.

Yükseköğretim Kurulu, Yükseköğretim Program Atlası. (https://yokatlas. yok.gov.tr/, erişim 20/01/2019)

YÜRÜK, Ayşe Tülin: “Anadolu Üniversitesi Hukuk Fakültesi'nde Klinik Hukuk Eğitimi Süreci Nasıl Başladı, Nasıl Devam Edecek?” Hukuk Öğretiminde Yeni Yaklaşımlar: Hukuk Klinikleri Sempozyumu, Anadolu Üniversitesi Hukuk Fakültesi, Eskişehir, 2013. 
